\title{
Estimation of gonotrophic cycle lengths and survival rates for vector mosquitoes of Japanese encephalitis in the suburbs of Bangkok, Thailand
}

\author{
Nat Malainual ${ }^{1)}$, Usavadee Thavara ${ }^{2)}$, Chitti Chansang ${ }^{2)}$ \\ and Motoyoshi MogI ${ }^{3)}$ \\ 1) Department of Parasitology, Faculty of Medicine Siriraj Hospital, \\ Bangkok, 10700 Thailand \\ 2) Division of Medical Entomology, National Institute of Health, Department of \\ Medical Sciences, Nonthaburi, 11000 Thailand \\ ${ }^{3)}$ Division of Parasitology, Department of Microbiology, Saga Medical \\ School, Saga, 849-8501 Japan
}

(Received: 5 February 1998; Accepted: 26 March 1998)

\begin{abstract}
Key words: Culex tritaeniorhynchus, Culex gelidus, Japanese encephalitis vector, gonotrophic cycle length, survival rate, Thailand
\end{abstract}

\begin{abstract}
Frequencies of blood meals and survival rates of vector mosquitoes are important parameters influencing transmission efficiency of pathogens. We applied the time series analysis proposed by Holmes and Birley (1987) for estimation of gonotrophic cycle lengths and survival rates of Culex tritaeniorhynchus and Cx. gelidus, Japanese encephalitis (JE) vectors in Thailand. Females of these species were collected at a buffalo shed and a pigsty in a suburban area near Bangkok during 30 and 24 consecutive nights, respectively. Specimens were dissected daily to determine the parity status by tracheation of ovaries. In total, 17,482 Cx. tritaeniorhynchus and $13,011 \mathrm{Cx}$. gelidus females were caught, including 15 and $19 \%$ of parous individuals, respectively. The time series analysis for the data set collected at the buffalo shed yielded a gonotrophic cycle length of 5 days and a survival rate per cycle of $20 \%$ for $C x$. tritaeniorhynchus and 8 days and $16 \%$ for $C x$. gelidus. From these estimates, daily survival rates were calculated as $72 \%$ and $80 \%$ for $C x$. tritaeniorhynchus and $C x$. gelidus, respectively. However, the data set collected at the pigsty did not yield significant results. Holmes and Birley's (1987) method could be an effective tool in epidemiological studies for Japanese encephalitis vectors, but its applicability is influenced by conditions at collection sites.
\end{abstract}

\section{INTRODUCTION}

Vector survival rates are a key parameter determining the transmission efficiency of pathogens by arthropods. Various methods have been proposed for survival estimation of female mosquitoes (Service, 1993). Among them, the method based on parous rates (Davidson, 1954) has widely been used due to its simplicity. However, the method assumes that the target popu- lation has stable age structure, which rarely is realized in the field. Furthermore, for estimation of daily survival rates, it requires gonotrophic cycle lengths (an interval between two successive blood meals) determined separately.

Birley and Rajagopalan (1981) introduced an innovative method based on time series analyses using daily numbers of total and parous females. An advantage of this method is that both gonotrophic cycle lengths and survival rates can be 
estimated from field data without assuming stable age structure. Holmes and Birley (1987) improved the method so as to remove spurious but significant correlations due to external factors such as weather. These methods or their modified versions were applied for survival estimation of malaria and other disease vectors in various geographical regions generally with successful results (Service, 1993).

Japanese encephalitis (JE), one of the important mosquito-borne diseases in Thailand, is now expanding its prevalence up to a thousand cases per year. The disease regularly occurs during the rainy season, corresponding with high densities of vector populations. Several studies of $\mathrm{JE}$ vectors in Thailand (Gould et al., 1974; Mori et al., 1983; Leake et al., 1986; Somboon et al., 1989; Ginglich et al., 1992) revealed that, besides Culex tritaeniorhynchus Giles, Cx. gelidus Theobald, Cx. fuscocephala Theobald, and $C x$. vishnui Theobald may be involved in transmission of $\mathrm{JE}$ virus. Moriet al. (1983) and Somboon et al. (1989) estimated daily survival rates of JE vectors by Davidson's (1954) method, assuming the gonotrophic cycle duration of 3-4 days.

This paper presents the result of a trial of applying Holmes and Birley's (1987) method to $C x$. tritaeniorhynchus and $C x$. gelidus in Pathum Thani, a suburban area near Bangkok. One feature in this area was that main blood source animals were protected by mosquito nets at night.

\section{Materials And Methods}

Mosquito collection. The study was done in Amphur Ladlumkaew, Pathum Thani Province, west of Bangkok. The area was mostly consisted of rice fields, including human houses with 962 residents and animal sheds with 50 cattle, 30 buffaloes, 20 goats and 17 pigs. Humans used mosquito nets when they slept. Most animal sheds were covered with mosquito nets after sunset. The other blood sources available in the area were dogs, chickens, ducks and wild water birds such as egrets. During the study, most rice fields had been filled with water due to frequent rains.

Mosquitoes were collected at two animal sheds, one keeping 12 buffaloes and the other keeping 5 pigs. The distances between the sites was about $1.5 \mathrm{~km}$. Traps used for mosquito sampling were modified from the Fujihira super light trap (Malainual, 1988) by using $1 \mathrm{~kg}$ dry ice instead of light as an attractant. This sampling method was adopted to keep the sampling efficiency constant and to exclude non-biting insects such as moths and beetles. Traps were hanged at $1.5 \mathrm{~m}$ above the ground under the eave of the animal sheds and were operated during 18:30-19:30 for 30 consecutive nights (October 4-November 3,1988 ) at the buffalo shed and 24 nights (October 10November 3 ) at the pigsty. Mean temperatures during the collection ranged from 24 to $28^{\circ} \mathrm{C}$. There were often weak or moderate winds, but they did not disturb flight activities of mosquitoes.

Collected mosquitoes were stored in an ice box and brought back to the laboratory for examination on the following day. Only unfed females were processed. After identification and count, $C x$. tritaeniorhynchus and $C x$. gelidus were dissected and the tracheation of ovaries was examined to distinguish between nulliparous and parous (Detinova, 1962). The maximum 100 females for each species were dissected. When more than 100 females were collected, numbers of parous females in total catches were calculated with parous rates for 100 samples.

Estimation. Gonotrophic cycle lengths and survival rates were estimated by the method of Holmes and Birley (1987). The key assumption of this method is that females having taken blood meals on day $t$ are parous when they take the next meal on day $t+d$. Hence, it is expected that there is positive correlation between the number of total females on day $t\left(T_{t}\right)$ and that of parous females on day $t+d\left(M_{t+d}\right)$. The actual procedure is to find a time lag 
( $d$ integer days) which yields significant cross-correlation coefficients (CCs) between $T_{t}$ and $M_{t+d}$. To remove spurious significant correlations, $T_{t}$ and $M_{t}$ filtered by the following formula were used for calculation of CCs;

$$
z_{t}=x_{t}-\alpha \times x_{t}-1
$$

where $z_{t}=$ time series filtered, $x_{t}=$ time series to be filtered, and $\alpha=$ autoregression parameter calculated as

$$
\alpha=\Sigma\left\{\left(x_{t}-\bar{x}\right) \times\left(x_{t-1}-\bar{x}\right)\right\} / \Sigma\left(x_{t-1}-\bar{x}\right)^{2} .
$$

Calculation of CCs followed a standard correlation coefficient formula. When CCs were larger than $2 \sqrt{\text { number of samples in }}$ time series, the departure from zero was regarded significant at $P<0.05$. Then, $d$ was adopted as a gonotrophic cycle length with a corresponding estimate of a survival rate per gonotrophic cycle $(p)$ as $p=$ $\sum M_{t+d} / \Sigma T_{t}$. Daily survival rates were calculated as the $d$ root of $p$. All the calculation was performed with a computer program written in BASIC.

\section{RESULTS}

Species composition and density. Nearly a thousand of female mosquitoes were collected each night, most of them belonging to $C x$. tritaeniorhynchus or $C x$. gelidus (Table 1). The trap operated at the buffalo shed collected 8 times more mosquitoes than the trap at the pigsty did. Of females captured at the buffalo shed, $54 \%$ were $C x$. tritaeniorhynchus, whereas, at the pigsty, this species occupied $70 \%$. Cx. gelidus represented $43 \%$ and $24 \%$ at each site, respectively. Other species of Culex, Mansonia, Anopheles and Aedes collectively were less than $10 \%$ of the totals at both collection sites.

Numbers of $C x$. tritaeniorhynchus and $C x$. gelidus females fluctuated widely from day to day at both sites (Table 2), but there were no tendencies for the population levels either to increase or to decrease. Correlations between numbers of the two species were significant at the buffalo shed $(r=0.89, t=10.50$, d.f. $=28, P<0.001)$ and the pigsty $(r=0.69, t=4.49$, d.f. $=22, P$ $<0.001)$. Numbers at the two collection sites did not correlate to each other for $C x$. tritaeniorhynchus $(r=0.06, t=0.296$, d.f. $=$ $22, P>0.05)$ and $C$. gelidus $(r=-0.12, t=$ -0.567 , d.f. $=22, P>0.05$ ).

Age structure. Parous rates fluctuated daily within the range of $0-56 \%$, but were generally low (Table 2). Parous rates for totals at each site were $22 \%$ or less irrespective of species. When the two sites were combined, parous rates were 15 and $19 \%$ for Cx. tritaeniorhynchus and $C x$. gelidus, respectively.

Survival rate estimation. Significant peaks of CCs between total and parous females were detected at a lag of 5 days for $C x$. tritaeniorhynchus and at a lag of 8 days for $C x$. gelidus at the buffalo shed (Fig. 1). Estimated survival rates per gonotrophic cycle were larger than the mean

Table 1. Species and numbers of female mosquitoes collected at animal sheds in Pathum Thani during

\begin{tabular}{|c|c|c|c|c|c|c|}
\hline \multirow{2}{*}{ Species } & \multicolumn{3}{|c|}{ Buffalo } & \multicolumn{3}{|c|}{ Pig } \\
\hline & Total & No./night* & $\%$ & Total & No./night* & $\%$ \\
\hline Cx. tritaeniorhynchus & 15,535 & 517.8 & 53.86 & 1,947 & 81.2 & 69.26 \\
\hline$C x$. gelidus & 12,342 & 411.4 & 42.79 & 669 & 27.9 & 23.80 \\
\hline Culex spp. & 771 & 257.0 & 2.67 & 169 & 7.0 & 6.01 \\
\hline Mansonia spp. & 144 & 48.0 & 0.50 & 20 & 0.8 & 0.71 \\
\hline Anopheles spp. & 16 & 5.3 & 0.06 & 5 & 0.2 & 0.18 \\
\hline Aedes spp. & 2 & 0.7 & 0.01 & 0 & 0.0 & 0.00 \\
\hline Unidentified specimens & 33 & 11.0 & 0.11 & 1 & 0.04 & 0.04 \\
\hline Total & 28,843 & 961.4 & 100.00 & 2,811 & 117.1 & 100.00 \\
\hline
\end{tabular}
the period of October 4-November 2, 1988.

* 30 nights at the buffalo shed and 24 nights at the pigsty. 
Table 2. Numbers and parity of $C x$. tritaeniorhynchus and $C x$. gelidus collected at animal sheds in Pathum Thani during the period of October 4-November 2, 1988.

\begin{tabular}{|c|c|c|c|c|c|c|c|c|c|c|c|c|}
\hline \multirow{3}{*}{ Day } & \multicolumn{6}{|c|}{ Cx. tritaeniorhynchus } & \multicolumn{6}{|c|}{ Cx. gelidus } \\
\hline & \multicolumn{2}{|l|}{$\cdot$} & Buffalo & \multicolumn{3}{|c|}{ Pig } & \multicolumn{3}{|c|}{ Buffalo } & \multicolumn{3}{|c|}{ Pig } \\
\hline & Total & Parous & $\mathrm{P} \% *$ & Total & Parous & $\mathrm{P} \% *$ & Total & Parous & $\mathrm{P} \% *$ & Total & Parous & $\mathrm{P} \% *$ \\
\hline 1 & 168 & 17 & 10 & —** & - & - & 73 & 8 & 11 & - & - & - \\
\hline 2 & 67 & 14 & 21 & - & - & - & 24 & 2 & 8 & - & - & - \\
\hline 3 & 43 & 3 & 7 & - & - & - & 5 & 0 & 0 & - & - & - \\
\hline 4 & 164 & 11 & 7 & - & - & - & 83 & 7 & 8 & - & 一 & - \\
\hline 5 & 237 & 18 & 8 & - & - & - & 151 & 25 & 16 & - & - & - \\
\hline 6 & 3,232 & 216 & 7 & - & - & - & 3,578 & 541 & 15 & - & - & - \\
\hline 7 & 1,577 & 64 & 4 & 71 & 9 & 13 & 832 & 177 & 21 & 8 & 1 & 13 \\
\hline 8 & 557 & 68 & 12 & 86 & 2 & 2 & 92 & 12 & 13 & 86 & 2 & 2 \\
\hline 9 & 604 & 63 & 10 & 192 & 36 & 19 & 341 & 53 & 16 & 64 & 12 & 19 \\
\hline 10 & 511 & 57 & 11 & 45 & 7 & 16 & 463 & 74 & 16 & 12 & 2 & 17 \\
\hline 11 & 782 & 238 & 30 & 43 & 3 & 7 & 630 & 179 & 28 & 32 & 4 & 13 \\
\hline 12 & 384 & 61 & 16 & 57 & 14 & 25 & 314 & 72 & 23 & 15 & 2 & 13 \\
\hline 13 & 238 & 46 & 19 & 198 & 40 & 20 & 30 & 8 & 27 & 57 & 15 & 26 \\
\hline 14 & 652 & 110 & 17 & 45 & 8 & 18 & 1,644 & 419 & 26 & 38 & 10 & 26 \\
\hline 15 & 491 & 76 & 16 & 201 & 28 & 14 & 412 & 49 & 12 & 76 & 10 & 13 \\
\hline 16 & 443 & 110 & 25 & 308 & 67 & 22 & 263 & 76 & 29 & 63 & 15 & 24 \\
\hline 17 & 487 & 119 & 24 & 192 & 58 & 30 & 161 & 49 & 30 & 58 & 17 & 29 \\
\hline 18 & 178 & 72 & 40 & 50 & 28 & 56 & 63 & 28 & 44 & 33 & 14 & 42 \\
\hline 19 & 601 & 239 & 40 & 70 & 33 & 47 & 166 & 74 & 45 & 20 & 11 & 55 \\
\hline 20 & 99 & 37 & 38 & 32 & 12 & 38 & 35 & 14 & 40 & 21 & 7 & 33 \\
\hline 21 & 450 & 129 & 29 & 20 & 7 & 35 & 76 & 21 & 28 & 4 & 1 & 25 \\
\hline 22 & 349 & 74 & 21 & 59 & 18 & 31 & 84 & 30 & 36 & 8 & 2 & 25 \\
\hline 23 & 861 & 159 & 19 & 44 & 5 & 11 & 279 & 52 & 19 & 10 & 2 & 20 \\
\hline 24 & 251 & 14 & 6 & 14 & 3 & 21 & 293 & 44 & 15 & 5 & 1 & 20 \\
\hline 25 & 568 & 11 & 2 & 77 & 10 & 13 & 450 & 39 & 9 & 24 & 1 & 4 \\
\hline 26 & 408 & 28 & 7 & 21 & 0 & 0 & 593 & 33 & 6 & 5 & 0 & 0 \\
\hline 27 & 207 & 41 & 20 & 10 & 0 & 0 & 104 & 25 & 24 & 55 & 7 & 13 \\
\hline 28 & 282 & 34 & 12 & 35 & 5 & 14 & 417 & 83 & 20 & 21 & 5 & 24 \\
\hline 29 & 371 & 60 & 16 & 66 & 19 & 29 & 233 & 20 & 9 & 13 & 1 & 8 \\
\hline 30 & 268 & 61 & 23 & 11 & 6 & 55 & 453 & 73 & 16 & 7 & 0 & 0 \\
\hline Total & 15,535 & 2,252 & 15 & 1,947 & 419 & 22 & 12,342 & 2,292 & 19 & 669 & 142 & 21 \\
\hline
\end{tabular}

* Percentage parous.

** Not collected.

Table 3. Population parameters estimated for Cx.tritaeniorhynchus and $C x$.gelidus collected at animal sheds in Pathum Thani during the period of October 4-November 2, 1988.

\begin{tabular}{lccccc}
\hline \hline \multirow{2}{*}{ Parameter } & \multicolumn{2}{c}{ Cx. tritaeniorhynchus } & & \multicolumn{2}{c}{ Cx. gelidus } \\
\cline { 5 - 6 } & Buffalo & Pig & & Buffalo & Pig \\
\hline Gonotrophic cycle length (day) & 5 & - & & 8 & - \\
Survival rate per cycle (\%) & 20 & - & & 16 & - \\
Daily survival rate (\%) & 72 & - & & 80 & -
\end{tabular}

parous rate for $C x$. tritaeniorhynchus but smaller for $C x$. gelidus (Tables 2 and 3 ). Daily survival rates assuming constancy during the cycle were within the range of
70-80\% (Table 3).

CCs were not significant for both species at the pigsty, therefore gonotrophic cycle lengths and survival rates could not be 


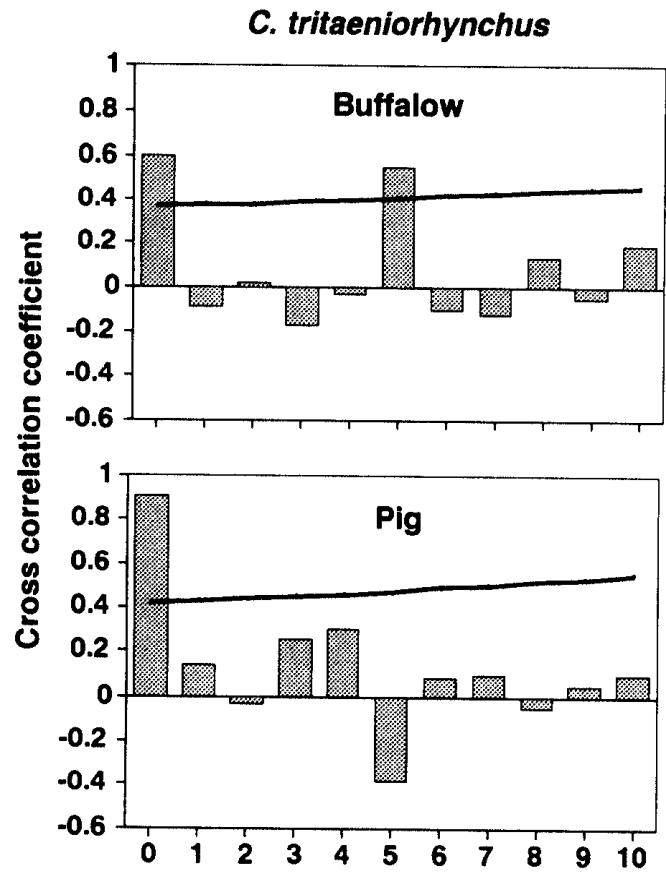

C. gelidus
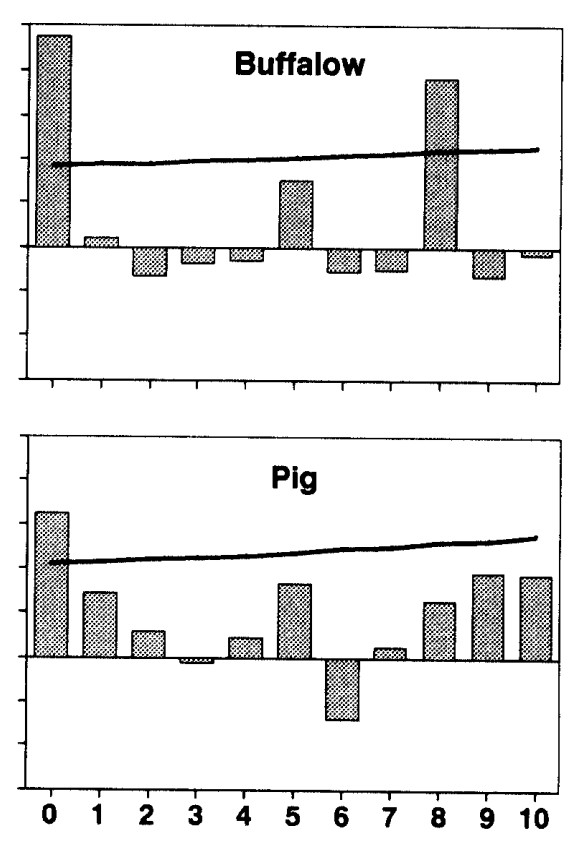

Lag (day)

Fig. 1. Cross-correlation coefficients (CCs) at specific time lag intervals between numbers of total and parous females for Cx.tritaeniorhynchus and Cx. gelidus collected at the buffalo shed and the pigsty. Solid lines on each panel indicates $95 \%$ confidence limits; CC values larger than this limit significantly depart from zero.

estimated by the method of Holmes and Birley (1987).

\section{Discussion}

Results obtained clearly indicated both advantages and limitations of the time series analysis of Holmes and Birley (1987). Data at the buffalo shed yielded significant CCs, which enabled estimation of gonotrophic cycle lengths and survival rates. In contrast, data at the pigsty failed to yield significant CCs. The two collection sites were in the same village, $1.5 \mathrm{~km}$ apart from each other. However, there were no correlations between mosquito numbers at the two sites. This means that fluctuation patterns in mosquito densities at each collection site reflected both mosquito abundance in the study area and micro conditions at each site. The latter include such factors as direction and strength of winds, and density and size of trees and architecture around each site. They would influence the spatial distribu- tion of flying mosquitoes (Bidlingmayer, 1975).

The difference in attractiveness between the two collection sites might also have contributed to the different fluctuation pattern in mosquito numbers. Buffaloes in the shed were more abundant and individually much larger than pigs in the pigsty. The buffaloes were mature, while the pigs were of 3 months after birth. Attraction ranges of baits for mosquitoes depend on the number and size of baits at least partly (Gillies and Wilkes, 1972; McIver and McElligott, 1989). Therefore, the buffalo shed was certainly much more attractive for host-seeking mosquitoes than the pigsty. In fact, 8 times more mosquitoes were collected at the buffalo shed. Probably, samples at the buffalo shed represented the mosquito populations in the study area better.

The gonotrophic cycle length of 5 days detected at the buffalo shed for Cx. tritaeniorhynchus was longer than 3 days determined in Japan by the mark-recapture 
method (Buei et al., 1980). The 3-days cycle corresponds to the shortest period observed in the laboratory (Kawai, 1969). The mean interval between two successive blood meals was about 4 days at $27^{\circ} \mathrm{C}$ (Kawai, 1969), therefore the 5-days cycle is a reasonable estimate. By the markrecapture study for CX.tritaeniorhynchus in Pakistan, 5-8 days were detected as the period from emergence to the first oviposition (Reisen et al., 1978). Birley and Rajagopalan's (1981) method used for $C x$. tarsalis Coquillett in California also detected a cycle of 5-7 days (McHugh, 1990).

For $C x$. gelidus, the cycles of 8 days was detected. Because little is known about bionomics of this species (Malainual, 1992), it is difficult to discuss further about adequacy of this estimate. It was provisionally treated as a gonotrophic cycle length. However, it is noted that, in the time series analysis, factors other than gonotrophic cycle lengths may yield significant CCs (Holmes and Birley, 1987).

Parous rates observed in this study were lower than 30-70\% reported for these species (Harada et al., 1967, 1968; Aslam et al., 1977; Reisen et al., 1986; Somboon et al., 1989), but were similar to 15$22 \%$ in some reports (Buei et al., 1982; Mori et al., 1983). Sampling in this study was limited to 1 hour after sunset. Parous rates of $C x$. tritaeniorhynchus might increase towards later part of night (Aslam et al., 1977), but Reisen et al. (1986) found that, on average, a half of the females attracted to cattle during 30 minutes after sunset were parous. Therefore, a short sampling time limited to evening was not a reason of relatively low parous rates. During the study, breeding habitats of the vectors were abundant due to wet rice fields. These habitats probably produced high numbers of new adults, lowering parous rates.

Protection of main blood source animals with mosquito nets also may have lowered parous rates. In addition, it may have made the detection of significant $C C$ peaks more difficult as exemplified for the data obtained at the pigsty. Increased difficulty in access to blood sources would make feeding success less synchronized, which could render feeding peaks indistinct. Impact of animal protection on mosquito populations and JE epidemiology, either desirable or undesirable for humans, deserves further research.

Daily survival rates calculated by Buei et al. (1982) and Mori et al. (1983) were $60 \%$ odd, because they combined low parous rates with a gonotrophic cycle length of 3 days. Our estimates with longer cycle lengths directly obtained for the target population are comparable to $70-90 \%$ in other reports.

Summarizing, Holmes and Birley's (1987) method could be an effective tool in studies of Japanese encephalitis vectors. However, it is noted that this method is not robust but rather sensitive to conditions at collection sites. Establishment of a standard sampling technique, which can increase the efficiency of this method, is desirable.

\section{ACKNOWLEDGMENTS}

We would like to thank Mr. Prakong Phan-Urai, the then Director, Division of Medical Entomology, for his encouragement. This study was supported by the Ministry of Health, Thailand, and the Japan International Cooperation Agency.

Reprint request should be addressed to N. Malainual, Division of Molecular Biology, TVW Telethon Institute for Child Health Research, P. O. Box 855, West Perth, Western Australia 6872.

\section{REFERENCES}

Aslam, Y., W. K. Reisen and M. Aslamkhan (1977) The influence of physiological age on the biting rhythm of Culex tritaeniorhynchus Giles (Diptera: Culicidae). Southeast Asian J. Trop. Med. Public Hlth., 8: 364-367.

Bidlingmayer, W. L. (1975) Mosquito flight paths in relation to the environment. Effect of vertical and horizontal visual barriers. Ann. Entomol. Soc. Am., 
68: $51-57$.

Birley, M.H. and P. K. Rajagopalan (1981) Estimation of the survival rates of Culex quinquefasciatus (Diptera: Culicidae). J. Med. Entomol., 18: 181-186.

Buei, K., S. Ito, H. Nakamura and M. Yoshida (1980) Field studies on the gonotrophic cycle of Culex tritaeniorhynchus. Jpn. J. Sanit. Zool., 31: 57-62.

Buei, K. and S. Ito (1982) The age-composition of field population and the survival rates in Culex tritaeniorhynchus Giles. Jpn. J. Sanit. Zool., 33: 2125.

Davidson, G. (1954) Estimation of the survival rate of anopheline mosquitoes in nature. Nature, 174: 792-793.

Detinova, T.S. (1962) Age-grading methods in Diptera of medical importance. Wld. Hlth. Org. Monogr. Ser., 47: 1-216.

Gillies, M. T. and T. J. Wilkes (1972) The range of attraction of animal baits and carbon dioxide for mosquitoes. Studies in a freshwater area of West Africa. Bull. Entomol. Res., 61: 389-404.

Gingrich, J. B., A. Nisalak, J. R. Latendresse, J. Sattabongkot, C. H. Hoke, J. Pomsdhit, C. Chantalakana, G. Satayaphanta, K. Uechiewcharnkit and B. L. Innis (1992) Japanese encephalitis virus in Bangkok: factors influencing vector infections in three suburban communities. J. Med. Entomol., 29: 436444.

Gould, D. J., R. Edelman, R. A. Grossman, A. Nisalak and M. F. Sulivan (1974) Study of Japanese encephalitis virus in Changmai Valley, Thailand. IV. Vector studies. Am. J. Epidemiol., 100: 49-56.

Harada, F., K. Moriya and T. Yabe (1967) Observations on the habits of feeding and oviposition of Culex tritaeniorhynchus Giles. Jpn. J. Appl. Entomol. Zool., 11: 83-89 (in Japanese with English summary).

Harada, F., K. Moriya and T. Yabe (1968) Observations on the habits of feeding and oviposition of Culex tritaeniorhynchus summorosus Dyar (II). Jpn. J. Sanit. Zool., 19: 230-236 (in Japanese with English summary).

Holmes, P. R. and M. H. Birley (1987) An improved method for survival rate analysis from time series of haematophagous dipteran populations. J. Anim. Ecol., 56: 427-440.

Kawai, S. (1969) Studies on the follicular development and feeding activity of the females of Culex tritaeniorhynchus with special reference to those in autumn. Trop. Med., 11: 145-169.
Leake, C. J., M. A. Ussery, A. Nisalak, C. H. Hoke, R. G. Andre and D. S. Burke (1986) Virus isolation from mosquitoes collected during the 1982 Japanese encephalitis epidemic in northern Thailand. Trans. R. Soc. Trop. Med. Hyg., 80: 831-837.

Malainual, A. (1988) Light trap. Bull. Dept. Med. Sci. Thai., 30: 235-238 (in Thai).

Malainual, N. (1992) Bionomics of Culex gelidus Theobald and its susceptibility to Japanese encephalitis virus. Dissertation for M.Sc. (Tropical Medicine), Mahidol University.

McHugh, C. P. (1990) Survivorship and gonotrophic cycle length of Culex tarsalis (Diptera: Culicidae) near Sheridan, Placer County, California. J. Med. Entomol., 27: 1027-1030.

McIver, S. B. and P. E. McElligott (1989) Effects of release rates on the range of attraction of carbon dioxide to some southwestern Ontario mosquito species. J. Am. Mosq. Control Assoc., 5: 6-9.

Mori, A., A. Igarashi, O. Charoensook, C. Khamboonruang, P. Leechanachai and J. Supawadee (1983) Virological and epidemiological studies on encephalitis in Chiang Mai area, Thailand, in the year of 1982. VII. Mosquito collection and virus isolation. Trop. Med., 24: 189-198.

Reisen, W. K., Y. Aslam, T. F. Siddiqui and A. Q. Khan (1978) A mark release-recapture experiment with Culex tritaeniorhynchus Giles. Trans. $R$. Soc. Trop. Med. Hyg., 72: 167-177.

Reisen, W. K., F. Mahmood, S. Niaz, K. Azra, T. Parveen, R. Mukhtar, Y. Aslam and T. F. Siddiqui (1986) Population dynamics of some Pakistan mosquitoes: temporal changes in reproductive status, age structure and survivorship of Anopheles culicifacies, An. stephensi and Culex tritaeniorhynchus. Ann. Trop. Med. Parasitol., 80: 77-95.

Service, M. W. (1993) Mosquito Ecology 2nd ed. 988 pp., Elsevier Science Publishhers, Ltd., London.

Somboon, P., W. Choochote, C. Khamboonruang, P. Keha, P. Suwanphanit, K. Sukontasan and P. Chaivong (1989) Studies on the Japanese encephalitis vectors in Amphoe Muang, Chiang Mai, Northern Thailand. Southeast Asian J. Trop. Med. Public Hlth., 20: 9-17. 


\section{摘}

\section{要}

タイ国バンコク近郊における日本脳炎媒介蚊の 吸血間隔之生存率の推定

Nat Malainual ${ }^{1)}$ Usavadee Thavara $^{2)}$ Chitti CHANSAHG ${ }^{2)}$ 茂木幹義 ${ }^{3)}$

1) Department of Parasitology, Faculty of Medicine Siriraj Hospital (Bangkok 10700, Thailand)

2) Division of Medical Entomology, National Institute of Health, Department of Medical Sciences (Nonthaburi 11000, Thailand) 3) 佐賀医科大学微生物学教室 （干849-8501 佐賀市鍋島 5-1-1）

疾病媒介蚊の吸血頻度之生存率は病原体の伝播効率に 影響する重要な変数である. 我々は Holmes and Birley
(1987) の時系列分析法により，夕イ国における日本脳炎 媒介蚊 Cx. tritaeniorhynchus 上Cx. gelidus の吸向間隔 と生存率を推定した。両種の雌成虫を水牛舎と豚舎でそ れぞれ30日間と 24 日間, 連夜, 採集した。採集個体は 解剖し, 卵巣の気管の形状から経産, 未経産を判定した。 合計 17,482 個体の Cx. tritaeniorhynchus \& 13,011 個 体の Cx. gelidus が採集され, 経産率は $15 \sim 22 \%$ で あった. 水牛舎で得られたデー夕の分析から, 吸血間隔 とその間の生存率は, Cx. tritaeniorhynchus については それぞれ 5 日と 20\%，Cx. gelidus については 8 日と 16\% と推定された. これらの数值から計算された日生 存率は，それぞれ， $72 \%$ と $80 \%$ であった。 しかし，豚 舎で得られたデー夕の分析からは統計的に有意な結果は 得られなかった. Holmes and Birley (1987)の法は日 本脳炎媒介蚊の疫学的研究に利用しうるが，その適用の 成否は採集場所の条件に影響される。 